\title{
FAKTOR YANG MEMPENGARUHI IMPLEMENTASI SAK ETAP PADA UMKM DENGAN KETIDAKPASTIAN LINGKUNGAN SEBAGAI VARIABEL MODERASI
}

\author{
Indah Anisykurlillah*, Bergas Rezqika \\ Jurusan Akuntansi, Fakultas Ekonomi, Universitas Negeri Semarang \\ indah_anis@mail.unnes.ac.id
}

\begin{abstract}
This research aims to determine the effect of educational background, business size, business age, understanding of technology, socialization and training on the Implementation of SAK ETAP and its effects when moderated by environmental uncertainty. The study population was oyster mushroom MSMEs that were spread in Temanggung Regency, a total of 48 MSMEs. Sampling using saturation sampling technique, then obtained a sample of 48 respondents for analysis. The data analysis technique used is the Moderate Regression Analysis (MRA) with the help of IBM SPSS Statistics 21 program. The results showed that socialization and training had a significant positive effect on the implementation of SAK ETAP. Environmental uncertainty strengthens the relationship of socialization and training to the implementation of SAK ETAP. Educational background, business size, and understanding of technology have no effect on the implementation of SAK ETAP. Environmental uncertainty cannot moderate the relationship of educational background and implementation of SAK ETAP. Environmental uncertainty cannot moderate the relationship between understanding technology and implementing SAK ETAP. The conclusions of this research indicate that the higher the frequency of socialization and training has an effect on the implementation of SAK ETAP and environmental uncertainty can be used as moderation because it is able to strengthen business size, business age and socialization and training.
\end{abstract}

Keywords: Implementation of SAK ETAP; Educational Background; Business Size; Business Age; Understanding of Technology; Socialization and Training; Environmental Uncertainty

\section{PENDAHULUAN}

Negara Indonesia merupakan salah satu negara berkembang, di mana sebuah negara berkembang sangat fokus akan pembangunan dan pertumbuhan ekonomi ke arah yang lebih baik. Salah satu bentuk usaha yang memberi kontribusi terhadap pertumbuhan dan perkembangan ekonomi adalah Usaha Mikro, Kecil dan Menengah (UMKM). Usaha Mikro, Kecil dan Menengah (UMKM) merupakan salah satu pilar penting dalam kegiatan ekonomi di berbagai sektor, yaitu: penyedia lapangan kerja yang terbesar, pemain penting dalam pengembangan kegiatan ekonomi lokal dan pemberdayaan masyarakat, pencipta pasar baru dan sumber inovasi, serta sumbangannya dalam menjaga neraca pembayaran melalui kegiatan ekspor (Undang-Undang Nomor 20 Tahun 2008).

Tuti \& Dwiyanti (2015) menyatakan bahwa pada tahun 2016, Indonesia telah menghadapi Asean Economic Community (AEC), dimana persaingan pasar akan semakin tinggi bagi 
pelaku UMKM. Untuk dapat mengembangkan usahanya, UMKM membutuhkan pendanaan yang cukup besar. Namun, sebagian besar UMKM hanya menggunakan modal pribadi dalam menjalankan usahanya, dan tidak ada pemisah antara uang pribadi dengan uang perusahaan.

Pemerintah Indonesia telah memberikan bantuan pendanaan kepada para UMKM yang dikenal dengan progam pembiayaan UMKM berupa Kredit Usaha Rakyat (KUR) yang tujuannya untuk membantu UMKM untuk meningkatkan usahanya. Namun kenyatan dilapangan mengatakan bahwa realisasi KUR pada tahun 2017 turun, dibandingkan dengan realisasi tahun 2016 (Rudiantoro \& Siregar, 2011). Afianti (2017) mengungkapkan bahwa belum adanya kesamaan pola pikir antara persyaratan Bank yang harus dipenuhi oleh UMKM, termasuk ketersediaan laporan keuangan dan Bussines Plan (rencana pengembangan usaha) merupakan kendala yang menyebabkan minimnya akses keuangan UMKM. Padahal dengan adanya laporan keuangan akan memungkinkan pemilik memperoleh data dan informasi yang tersusun secara sistematis.

Ada beberapa faktor yang menyebabkan masih minimnya kesadaran para pelaku UMKM di dalam membuat laporan akuntansi, seperti kurangnya SDM yang memadai di dalam melakukan pembukuan, serta biaya yang dirasa cukup tinggi yang harus di keluarkan untuk melakukan hal tersebut. Banyak UMKM yang belum sadar akan pentingnya pencatatan akuntansi atau laporan keuangan dalam usahanya karena terlalu fokus pada proses produksi dan operasionalnya (Mulyaga, 2016).

Berdasarkan kondisi tersebut, Ikatan Akuntan Indonesia (IAI) melalui Dewan Standar Akuntansi Keuangan (DSAK) pada tanggal 19 Mei 2009 telah mengesahkan Standar Akuntansi untuk Entitas Tanpa Akuntabilitas Publik (SAK ETAP) yang ditujukan khusus bagi entitas tanpa akuntabilitas publik yaitu salah satunya UMKM dan telah berlaku efektif per 1 Januari 2011. Meskipun SAK ETAP wajib diimplementasikan pada Januari 2011, UMKM masih kesulitan untuk menyiapkan laporan keuangan sesuai dengan standar (Yanto et $a l ., 2017)$. SAK ETAP tidak begitu saja dapat diterima oleh UMKM, masih banyak UMKM yang tidak menerapkan pembukuan yang sesuai dengan standar.

Seperti penelitian yang telah dilakukan oleh Tuti \& Dwiyanti (2015) menunjukan bahwa banyak responden (UMKM) yang belum pernah mendapatkan informasi dan sosialisasi, sehingga SAK ETAP sebagai pedoman standar akuntansi UMKM belum bisa diterapkan karena UMKM belum paham terkait SAK ETAP itu sendiri. Hal ini berlawanan dengan harapan bahwa dengan adanya SAK ETAP semestinya dapat menjadi pedoman dalam penyusunan laporan keuangan bagi UMKM, oleh karena itu perlu adanya informasi dan sosialisasi yang lebih intens dari pihak Pemerintah terhadap UMKM, mengingat jumlah pertumbuhan UMKM yang semakin meningkat setiap tahunnya.

Seiring berjalannya waktu mulai banyak penelitian bertemakan SAK ETAP yang bervariatif. Rudiantoro \& Siregar (2012) menjelaskan prospek implementasi SAK ETAP masih terkendala dengan rendahnya responden (UMKM) dalam memahami pentingnya pembukuan bagi usahanya, serta minimnya informasi dan sosialisasi dari Pemerintah semenjak diterapkannya SAK ETAP. Akan tetapi faktor dimana koperasi ataupun UMKM dapat memahami ataupun menerapkan SAK ETAP tidak terbatas pada faktor informasi dan sosialisasi, melainkan banyak faktor yang dapat memengaruhi penerapan SAK ETAP, seperti: latar 
belakang pendidikan pengusaha, budaya organisasi, ukuran usaha, umur usaha, persepsi pengusaha, pelatihan akuntansi, ketidakpastian lingkungan dan lain sebagainya.

Research gap, seperti penelitian Sariningtyas \& Diah (2011) yang menemukan bahwa latar belakang pendidikan pemilik tidak berpengaruh terhadap kebutuhan SAK ETAP dan pemahaman teknologi berpengaruh terhadap kebutuhan SAK ETAP. Aufar (2014) menemukan bahwa ukuran usaha, umur usaha dan latar belakang pendidikan berpengaruh terhadap implemementasi SAK ETAP. Soraya \& Mahmud (2016) menyatakan bahwa ukuran usaha berpengaruh terhadap kebutuhan SAK ETAP, sedangkan umur usaha tidak berpengaruh terhadap kebutuhan SAK ETAP. Zahro \& Wahyundaru (2015) membuktikan bahwa latarbelakang penddikan dan ukuran usaha berpengaruh terhadap kebutuhan SAK ETAP sedangkan pemahaman teknologi dan sosialisasi pelatihan tidak berpengaruh terhadap kebutuhan SAK ETAP. Sitoresmi \& Fuad (2013) menyatakan bahwa ukuran usaha dan umur usaha berpengaruh terhadap implementasi SAK ETAP sedangkan ketidakpastian linkungan tidak dapat memoderasi ukuran usaha dan umur usaha terhadap implementsi SAK ETAP.

Tujuan penelitian ini adalah untuk mengetahui pengaruh latar belakang pendidikan, ukuran usaha, umur usaha, pemahaman teknologi, serta sosialisasi dan pelatihan terhadap implementasi SAK ETAP, serta untuk mengetahui apakah ketidakpastian lingkungan mampu memoderasi hubungan latar belakang pendidikan, ukuran usaha, umur usaha, pemahaman teknologi, serta sosialisasi dan pelatihan terhadap implementasi SAK ETAP.

Teori yang digunakan dalam penelitian ini adalah Unified Theory of
Acceptance and Use of Technology (UTAUT) dan Human Capital Theory. UMKM seharusnya melakukan pencatatan dan pelaporan dalam usahanya sesuai dengan standar yang ada. UMKM dalam menerapkan pembukuan sesuai standar dipengaruhi oleh beberapa faktor, baik faktor interal maupun eksternal. UTAUT yang dikembangkan oleh Venkatesh et al., (2011) dengan merumuskan empat macam penentu inti (core determinant) suatu niat dan pengguna teknologi informasi (SAK ETAP) dengan empat moderator dari hubungan pokok (key relationship). Keempat core determinant yang dimaksud ini adalah ekspektasi terhadap kinerja, ekspektasi terhadap upaya, pengaruh sosial, dan kondisi yang mendukung. Teori ini digunakan berdasarkan saran yang diberikan oleh penelitian sebelumnya yaitu Mulyaga (2016) sehingga UTAUT pada penelitian ini digunakan sebagai landasan teori untuk memperkuat variabel ukuran perusahaan, umur perusahaan, pemahaman teknologi serta sosialisasi dan pelatihan.

Human Capital Theory yang dikembangkan oleh Becker (1965) yang berpendapat bahwa investasi sumber daya manusia mempunyai pengaruh yang besar terhadap peningkatan produktivitas, peningkatan produktivitas tenaga kerja ini dapat didorong melalui pendidikan dan pelatihan. Teori ini menyatakan bahwa manusia merupakan suatu bentuk kapital atau barang modal serta sumber daya manusia mempunyai pengaruh besar terhadap peningkatan produktivitas, peningkatan produktivitas dapat didorong melalui pendidikan. Teori ini digunakan sebagai landasan teori untuk memperkuat variabel latar belakang pendidikan pemilik.

$H_{1}$ : Latar belakang pendidikan pemilik berpengaruh positif terhadap 


\section{implementasi SAK ETAP pada UMKM}

Human Capital Theory menyatakan bahwa pendidikan menanamkan ilmu pengetahuan, ketrampilan, dan nilai-nilai kepada manusia dan karenanya mereka dapat meningkatkan kapasitas belajar dan produktivitasnya. Jadi pendidikan dapat berfungsi meningkatkan produktivitas dan berperan sebagai sinyal kemampuan (Zahro \& Wahyundaru, 2015).

Pendidikan formal pemilik dapat berpengaruh terhadap pengetahuan tentang akuntansi, karena materi akuntansi didapatkan pada jenjang pendidikan yang lebih tinggi, pengetahuan akuntansi yang lebih tinggi terutama didapatkan apabila seseorang menempuh pendidikan dengan jurusan akuntansi. Menurut (Gray, Adams, González, Adams, \& Mcnicholas, 2010) pendidikan juga dapat berpengaruh terhadap peningkatkan kemampuan menyerap (termasuk kemampuan akuisisi, asimilasi, transformasi, dan eksploitasi) dari pengetahuan baru.

Hasil penelitian Rudiantoro \& Siregar (2012) menyatakan jenjang pendidikan terakhir berpengaruh positif terhadap pemahaman pengusaha terkait SAK ETAP. Hasil penelitian Aufar (2014) juga menyatakan bahwa pendidikan terakhir pemilik UMKM berpengaruh terhadap penggunaan informasi akuntansi.

\section{$\mathrm{H}_{2}$ : Ukuran usaha berpengaruh positif terhadap implementasi SAK ETAP pada UMKM}

UTAUT menjelaskan bahwa adopsi sistem informasi dapat digunakan apabila adanya kondisi yang mendukung (Facilitating Condition). Menurut Gray et al., (2010) semakin besar ukuran perusahaan berimplikasi perusahaan mempunyai sumber daya yang lebih besar dan juga lebih mampu memperkerjakan karyawan dengan keahlian yang lebih baik, sehingga mendukung implementasi SAK ETAP.

Rudiantoro \& Siregar (2012) menemukan bahwa ukuran usaha dapat mempengaruhi pemikiran pengusaha terkait dengan kompleksitas dan semakin tingginya tingkat transaksi perusahaan sehingga diharapkan dengan makin besarnya ukuran usaha dapat mendorong seseorang untuk berpikir dan belajar terkait solusi untuk menghadapinya.

\section{H3: Umur usaha bepengaruh positif terhadap implementasi SAK ETAP pada UMKM}

Wulandary \& Hidayat (2012) mengatakan umur menentukan cara berpikir, bertindak dan berperilaku perusahaan dalam melakukan operasionalnya. Umur usaha atau lama usaha dalam hal ini adalah lamanya suatu UMKM berdiri atau umur UMKM semenjak usaha tersebut berdiri, sampai pada saat penulis melakukan penelitian ini. Rudiantoro \& Siregar (2012) berpendapat lama suatu usaha berdiri dapat memberi pengaruh terhadap persepsi pengusaha UMKM yang terbentuk. Umur perusahaan yang sudah berjalan cukup lama memungkinkan pengusaha tersebut lebih mementingkan laporan keuangan. Semakin lama umur usaha berdiri akan mendorong UMKM dalam menerapkan pembukuan dan pelaporan sesuai SAK ETAP.

\section{H4: Pemahaman teknologi bepengaruh positif terhadap implementasi SAK ETAP pada UMKM}

Pemahaman dalam penelitian ini lebih menekankan pada pemahaman terhadap pentingnya teknologi informasi akuntansi bagi para pelaku Usaha Mikro, Kecil, dan Menengah (UMKM) karena informasi akuntansi ini dapat digunakan sebagai pedoman dalam pengambilan keputusan serta mencapai efisiensi dan efektivitas kegiatan usaha. Berdasarkan 
UTAUT yang dikembangkan oleh Venkatesh et al., (2011) menyatakan bahwa penentu pengguna teknologi informasi salah satunya adalah ekspektasi terhadap upaya (effort expectancy) yakni sejauh mana tingkat kemudahan yang dirasakan oleh individu dalam menggunakan sistem.

Penelitian Pratiwi \& Hanafi (2016) yang menunjukkan bahwa pemahaman teknologi informasi oleh pemilik UMKM berpengaruh positif dan signifikan terhadap penerapan SAK ETAP. Kondisi tersebut menunjukkan bahwa seorang pemilik UMKM yang mempunyai pemahaman teknologi informasi yang lebih baik cenderung menginginkan untuk dapat menggunakan SAK ETAP yang lebih baik.

$\begin{array}{clr}\text { H}_{5} \text { :Sosialisasi } & \text { dan } & \text { pelatihan } \\ \text { bepengaruh } & \text { positif } & \begin{array}{l}\text { terhadap } \\ \text { implementasi }\end{array} \\ \text { UMKM } & \text { SAKAP pada }\end{array}$

Sosialisasi yang diterima pemilik UMKM merupakan pengaruh sosial yang dapat mempengaruhi persepsi pemilik UMKM untuk menerapkan SAK ETAP. Menurut (Hasibuan, 2006) pelatihan (training) dimaksudkan untuk memperbaiki penguasaan berbagai ketrampilan dan teknik pelaksanaan kerja tertentu, terinci dan rutin. Sosialisasi dan pelatihan yang dijalankan jelas sangat berpengaruh pada pemahaman dan kemauan pelaku UMKM dalam menerapkan SAK ETAP. Dalam proses sosialisasi untuk meningkatkan pengetahuan mengenai SAK ETAP memang diperlukan adanya kontinuitas dan konsistensi untuk mensosialisasikan SAK ETAP ke seluruh pihak terkait secara menyeluruh di seluruh Indonesia, baik dilakukan oleh IAI yang telah membuat standar tersebut maupun secara kerjasama dengan institusi lainnya. Penelitian Firmansyah (2013) dan Solovida (2003) yang menyatakan bahwa pelatihan berpengaruh terhadap penggunaan sistem informasi akuntansi pada usaha kecil. Pelatihan berhubungan positif terhadap penyediaan informasi akuntansi untuk membuat keputusan dalam perusahaan kecil.

$\mathrm{H}_{6}$ :Ketidakpastian

lingkungan

memoderasi pengaruh latar
belakang pendidikan pemilik
UMKM terhadap implementasi
SAK ETAP

Ketidakpastian

lingkungan merupakan faktor kontinjensi yang penting karena dapat menyebabkan proses perencanaan dan kontrol menjadi lebih sulit. Semakin tinggi tingkat pendidikan pemilik atau manajer maka akan semakin cepat dalam memprediksi kondisi lingkungan eksternal yang dapat mempengaruhi operasional usahanya. Adanya ketidakpastian lingkungan yang tinggi dengan pendidikan pemilik yang tinggi maka diperlukan informasi akuntansi untuk menanggulangi kompleksitas dari lingkungan (Milliken, 1987). Maka ketidakpastian lingkungan akan mempengaruhi hubungan antara latar belakang pendidikan terhadap implementasi SAK ETAP pada UMKM.

$\mathrm{H}_{7}$ :Ketidakpastian lingkungan

memoderasi pengaruh ukuran
usaha UMKM
implementasi SAK ETAP

Semakin besar ukuran usaha yang dimiliki UMKM akan memberikan pengaruh dalam implementasi SAK ETAP dengan segala ketidakpastian lingkungan yang mungkin terjadi. SAK ETAP sebagai soft technology dapat dijadikan sebuah sistem untuk lebih bisa meminimalisasi bentuk resiko-resiko yang mungkin terjadi, baik dari dalam ataupun dari luar perusahaan. Kompleksitas kegiatan operasional perusahaan berbanding lurus dengan ukuran usaha suatu perusahaan, sehingga semakin besar 
skala usaha UMKM berimplikasi pada semakin besarnya resiko yang ditimbulkan dari ketidakpastian lingkungan. Maka ketidakpastian lingkungan akan mempengaruhi hubungan antara ukuran usaha terhadap implementasi SAK ETAP pada UMKM.

\section{Hs:Ketidakpastian lingkungan memoderasi pengaruh umur usaha UMKM terhadap implementasi SAK ETAP}

Umur usaha menentukan pola pikir perusahaan dalam bertindak dalam menjalankan operasional perusahaannya. Umur usaha menentukan kedewasaan pemilik untuk mengambil sebuah keputusan. Semakin lama perusahaan tersebut berdiri maka kebutuhan untuk menggunakan informasi akuntansi dipengaruhi oleh perubahan-perubahan yang terjadi di lingkungan usahanya. Hal tersebut disebabkan karena semakin kompleks permasalahan yang akan dihadapi UMKM. Tidak hanya itu, semakin lama perusahaan berdiri akan memerlukan lebih banyak persiapan dalam menghadapi persaingan usaha guna mempertahankan dan mengembangkan usahanya lebih besar lagi. SAK ETAP sebagai soft technology dapat dijadikan sebuah sistem untuk lebih bisa meminimalisasi bentuk resiko-resiko yang mungkin terjadi, baik dari dalam ataupun dari luar perusahaan. Kompleksitas kegiatan operasional perusahaan berbanding lurus dengan dengan umur usaha, sehingga semakin lama umur usaha UMKM berpengaruh pada semakin besarnya resiko yang ditimbulkan dari ketidakpastian lingkungan. Maka ketidakpastian lingkungan akan mempengaruhi hubungan antara umur usaha terhadap implementasi SAK ETAP pada UMKM.

\section{H9:Ketidakpastian lingkungan memoderasi pengaruh pemahaman}

\section{teknologi UMKM terhadap implementasi SAK ETAP}

Pemahaman individu merupakan pemahaman seluruh kepribadiannya dengan seluruh latar belakang dan interaksinya dengan lingkungannya (Sariningtyas \& Diah, 2011). Semakin baik pemahaman teknologi yang diterapkan oleh UMKM maka akan berdampak pada terciptanya efektifitas dan efisiensi dalam mengatasi ketidakpastian lingkungan yang dihadapi UMKM untuk mencapai tujuan usaha. Berdasarkan UTAUT menyatakan bahwa penentu pengguna teknologi informasi salah satunya adalah ekspektasi terhadap upaya (effort expectancy) yakni sejauh mana tingkat kemudahan yang dirasakan oleh individu dalam menggunakan sistem. Semakin tinggi pemahaman teknologi informasi yang dimiliki oleh para pelaku UMKM, akan memudahkan untuk mengatasi ketidakpastian yang timbul dan memberikan kontribusi yang nyata terhadap implementasi SAK ETAP bagi UMKM. Maka ketidakpastian lingkungan akan mempengaruhi hubungan antara pemahaman teknologi terhadap implementasi SAK ETAP pada UMKM.

\section{$H_{10}$ :Ketidakpastian lingkungan memoderasi pengaruh sosialisasi dan pelatihan UMKM terhadap implementasi SAK ETAP}

Pemahaman UMKM rang
diperoleh dari pelatihan ataupun
sosialisasi erat kaitannya dengan keadaan
lingkungan organisasi yang mendukung.
Semakin baik kemampuan UMKM dalam
memprediksi resiko-resiko dari
ketidakpastian lingkungan berimplikasi
pada semakin baiknya operasional
perusahaan. Duncan (2012) menyatakan
untuk mengoptimalkan efektivitas
organisasi maka organisasi tersebut perlu
berinteraksi dengan lingkungan dalam
ataupun luar organisasi sehingga mampu
membuat beberapa perubahan yang
sosialisasi erat kaitannya dengan keadaan lingkungan organisasi yang mendukung. Semakin baik kemampuan UMKM dalam memprediksi resiko-resiko dari ketidakpastian lingkungan berimplikasi pada semakin baiknya operasional perusahaan. Duncan (2012) menyatakan untuk mengoptimalkan efektivitas organisasi maka organisasi tersebut perlu berinteraksi dengan lingkungan dalam ataupun luar organisasi sehingga mampu membuat beberapa perubahan yang 
diperlukan sesuai dengan ketidakpastian lingkungan.

Dengan adanya pelatihan dan sosialisasi akan berdampak pada profesionalisme dalam manajemen. Pemilik atau manajer perusahaan yang sering mengikuti pelatihan akuntansi dan mengalami ketidakpastian lingkungan akan membutuhkan informasi akuntansi untuk mengatasi perubahan-perubahan yang terjadi di lingkungan usahanya. Maka ketidakpastian lingkungan akan mempengaruhi hubungan antara sosialisasi dan pelatihan terhadap implementasi SAK ETAP pada UMKM.

\section{METODE PENELITIAN}

Jenis penelitian ini menggunakan pendekatan kuantitatif. Data dalam penelitian ini adalah data primer. Populasi dalam penelitian ini adalah UMKM jamur tiram di Kabupaten Temanggung sebanyak 48 UMKM. Sampel penelitian ini sebanyak 48 responden yaitu UMKM jamur tiram di Kabupaten Temanggung. Teknik pengambilan sampel dilakukan dengan metode saturation sampling sehingga seluruh populasi juga digunakan sebagai sampel penelitian.

Penelitian ini menggunakan tujuh variabel penelitian yang terdiri dari satu variabel dependen, lima variabel independen, dan satu variabel moderasi. Variabel dependen dalam penelitian ini adalah implementasi SAK ETAP. Variabel independen dalam penelitian ini adalah latar belakang pendidikan pemilik, ukuran usaha, umur usaha, pemahaman teknologi, sosialisasi dan pelatihan. Sedangkan variabel moderasi dalam penelitian ini adalah ketidakpastian lingkungan. Definisi operasional variabel dapat dilihat pada tabel 1 berikut ini:

Tabel 1. Definisi Operasional Variabel

\begin{tabular}{|c|c|c|c|c|}
\hline No & Variabel & Definisi & Indikator & Pengukuran \\
\hline 1. & $\begin{array}{l}\text { Implementasi } \\
\text { SAK ETAP }\end{array}$ & $\begin{array}{lr}\text { Praktik pelaksanaan } \\
\text { prosedur akuntansi yang } \\
\text { dilakukan oleh para } \\
\text { pelaku UMKM } \\
\text { mencatat untuk } \\
\text { transaksi } & \text { setiap } \\
\text { dalam } & \text { ekonomi } \\
\text { operasionalnya } & \text { dengan } \\
\text { berpedoman } & \text { SAK } \\
\text { ETAP (Azis et al., } \\
\text { 2015). }\end{array}$ & $\begin{array}{l}\text { 1. Siklus akuntansi } \\
\text { laporan keuangan } \\
\text { SAK ETAP } \\
\text { 2. Pencatatan } \\
\text { persediaan } \\
\text { 3. Kelengkapan } \\
\text { laporan keuangan } \\
\text { 4. Frekuensi laporan } \\
\text { keuangan } \\
\text { 5. Kepatuhan } \\
\text { terhadap } \\
\text { ETAP SAK } \\
\text { Sumber: IAI (2009), } \\
\text { Wahyudin \& Khafid } \\
\text { (2013), Mulyaga } \\
\text { (2016) }\end{array}$ & $\begin{array}{l}\text { Skala semantic } \\
\text { defferensial } \\
\text { 1: Tidak pernah } \\
\text { melaksanakan } \\
\text { 2: Pernah } \\
\quad \text { melaksanakan } \\
\text { 3: Kadang- } \\
\text { kadang } \\
\text { melaksanakan } \\
\text { 4: Sering } \\
\text { melaksanakan } \\
\text { 5: Selalu } \\
\text { melaksanakan }\end{array}$ \\
\hline 2. & $\begin{array}{l}\text { Latar belakang } \\
\text { pendidikan } \\
\text { pemilik }\end{array}$ & $\begin{array}{l}\text { Latar Belakang } \\
\text { pendidikan pemilik } \\
\text { adalah tingkat } \\
\text { pendidikan yang } \\
\text { dimiliki oleh pemilik } \\
\text { UMKM } \\
\text { (Rudiantoro \& Siregar, }\end{array}$ & $\begin{array}{l}\text { 1. SMP } \\
\text { 2. SMA } \\
\text { 3. Diploma } \\
\text { 4. S1 } \\
\text { 5. S2 } \\
\text { Sumber: Rudiantoro } \\
\text { \& Siregar (2012) }\end{array}$ & $\begin{array}{l}\text { SMP : } 1 \\
\text { SMA : } 2 \\
\text { Diploma }: 3 \\
\text { S1 }: 4 \\
\text { S2 : } 5\end{array}$ \\
\hline
\end{tabular}


Faktor Yang Mempengaruhi.... (Indah, Bergas)

\begin{tabular}{|c|c|c|c|c|}
\hline $\begin{array}{c}\text { No } \\
\text {. }\end{array}$ & Variabel & Definisi & Indikator & Pengukuran \\
\hline 3. & Ukuran Usaha & $\begin{array}{l}2012) \text {. } \\
\text { Ukuran usaha } \\
\text { merupakan ukuran yang } \\
\text { menunjukkan besar } \\
\text { kecilnya sebuah } \\
\text { perusahaan yang dapat } \\
\text { diukur dari total aktiva, } \\
\text { total pendapatan, dan } \\
\text { jumlah tenaga kerja } \\
\text { yang dimiliki } \\
\text { perusahaan } \\
\text { Rudiantoro \& Siregar } \\
\text { (2012). }\end{array}$ & $\begin{array}{l}\text { 1. Jumlah tenaga } \\
\text { kerja } \\
\text { 2. Total aktiva } \\
\text { 3. Total pendapatan } \\
\text { Sumber: Seftianne, } \\
\text { (2011) }\end{array}$ & $\begin{array}{l}\text { 1. Sangat kecil } \\
\text { 2. Kecil } \\
\text { 3. Sedang } \\
\text { 4. Besar } \\
\text { 5. Sangat besar }\end{array}$ \\
\hline 4. & Umur Usaha & $\begin{array}{lr}\text { Umur } & \text { perusahaan } \\
\text { sebagai awal perusahaan } \\
\text { melakukan aktivitas } \\
\text { operasional ringga } \\
\text { dapat mempertahankan } \\
\text { going } \\
\text { concern perusahaan } \\
\text { tersebut } \\
\text { mempertahankan atau } \\
\text { eksistensi dalam dunia } \\
\text { bisnis. } \\
\text { (Nugroho, 2012) }\end{array}$ & $\begin{array}{lr}\text { Waktu (dalam tahun) } \\
\text { sejak } & \text { pendirian } \\
\text { perusahaan } & \text { sampai } \\
\text { dengan } & \text { penelitian } \\
\text { dilakukan. } & \end{array}$ & $\begin{array}{l}\text { 1. Sangat kecil } \\
\text { 2. Kecil } \\
\text { 3. Sedang } \\
\text { 4. Besar } \\
\text { 5. Sangat besar }\end{array}$ \\
\hline 5. & $\begin{array}{l}\text { Pemahaman } \\
\text { Teknologi }\end{array}$ & $\begin{array}{l}\text { Proses perbuatan atau } \\
\text { cara individu dalam } \\
\text { memahami pentingnya } \\
\text { informasi akuntansi } \\
\text { berbasis teknologi yang } \\
\text { digunakan } \\
\text { mengolah untuk } \\
\text { termasuk memproses, } \\
\text { memperoleh, menyusun, } \\
\text { serta menyimpan data } \\
\text { dengan berbagai cara } \\
\text { untuk menghasilkan } \\
\text { akuntansi } \\
\text { berkualitas yang } \\
\text { (Sitoresmi \& Fuad, } \\
\text { 2013) }\end{array}$ & $\begin{array}{l}\text { 1. Penggunaan sistem } \\
\text { manual ke } \\
\text { komputer. } \\
\text { 2. Database yang } \\
\text { berbasis teknologi } \\
\text { informasi. } \\
\text { 3. Software akuntansi. } \\
\text { 4. Jaringan internet. } \\
\text { 5. Pemeliharaan atau } \\
\text { perbaikan } \\
\text { peralatan. }\end{array}$ & $\begin{array}{l}\text { Skala likert 1-5 } \\
\text { 1: Sangat Tidak } \\
\quad \text { Setuju } \\
\text { 2: Tidak Setuju } \\
\text { 3: Ragu-ragu } \\
\text { 4: Setuju } \\
\text { 5: Sangat Setuju }\end{array}$ \\
\hline 6. & $\begin{array}{l}\text { Sosialisasi } \\
\text { Pelatihan }\end{array}$ & $\begin{array}{lr}\text { Proses mengajarkan } \\
\text { keahlian dan } \\
\text { memberikan } \\
\text { pengetahuan yang perlu, } \\
\text { serta sikap supaya }\end{array}$ & $\begin{array}{l}\text { 1. Sumber-sumber } \\
\text { sosialisasi dan } \\
\text { pelatihan SAK } \\
\text { ETAP } \\
\text { 2. Keikutsertaan }\end{array}$ & $\begin{array}{l}\text { Skala likert 1-5 } \\
\text { 1: Sangat Tidak } \\
\quad \text { Setuju } \\
\text { 2: Tidak Setuju } \\
\text { 3: Ragu-ragu }\end{array}$ \\
\hline
\end{tabular}




\begin{tabular}{|c|c|c|c|c|}
\hline No & Variabel & Definisi & Indikator & Pengukuran \\
\hline & & $\begin{array}{l}\text { mereka dapat } \\
\text { melaksanakan } \\
\text { tanggungjawabnya } \\
\text { dengan standar } \\
\text { (Cushway, 1994) }\end{array}$ & $\begin{array}{l}\text { responden dalam } \\
\text { kegiatan } \\
\text { sosialisasi/ } \\
\text { pelatihan.Tindak } \\
\text { lanjut dari } \\
\text { perolehan } \\
\text { informasi } \\
\text { 3. Perlunya pelatihan } \\
\text { semua bidang } \\
\text { usaha untuk } \\
\text { meningkatkan } \\
\text { kinerja (dalam } \\
\text { 4. Ketersediaan } \\
\text { mengikuti } \\
\text { pelatihan } \\
\text { 5. Waktu } \\
\text { tahun) sejak } \\
\text { pendirian } \\
\text { perusahaan sampai } \\
\text { dengan penelitian } \\
\text { dilakukan.tingnya } \\
\text { pelatihan untuk } \\
\text { memperbaiki } \\
\text { kinerja } \\
\text { Sumber: (Rudiantoro } \\
\text { \& Siregar, 2012) }\end{array}$ & $\begin{array}{l}\text { 4: Setuju } \\
\text { 5: Sangat Setuju }\end{array}$ \\
\hline \multirow[t]{2}{*}{7.} & $\begin{array}{l}\text { Ketidakpastian } \\
\text { Lingkungan }\end{array}$ & $\begin{array}{l}\text { Rasa ketidakmampuan } \\
\text { seseorang untuk } \\
\text { memprediksi sesuatau } \\
\text { secara akurat dari } \\
\text { seluruh faktor sosial dan }\end{array}$ & $\begin{array}{l}\text { 1. Informasi yang } \\
\text { berkaitan dengan } \\
\text { kondisi usaha di } \\
\text { masa yang akan } \\
\text { datang }\end{array}$ & $\begin{array}{l}\text { Skala likert 1-5 } \\
\text { 1:Sangat Tidak } \\
\quad \text { Setuju } \\
\text { 2: Tidak Setuju } \\
\text { 3: Ragu-ragu }\end{array}$ \\
\hline & & $\begin{array}{l}\text { fisik yang secara } \\
\text { langsung mempengaruhi } \\
\text { perilaku pembuatan } \\
\text { keputusan orang-orang } \\
\text { dalam organisasi. } \\
\text { (Milliken, 1987) }\end{array}$ & $\begin{array}{l}\text { 2. Informasi tentang } \\
\text { pengaruh faktor- } \\
\text { faktor eksternal } \\
\text { 3. Informasi non } \\
\text { ekonomi }\end{array}$ & $\begin{array}{l}\text { 4: Setuju } \\
\text { 5: Sangat Setuju }\end{array}$ \\
\hline
\end{tabular}

Sumber: Rangkuman Penulis, 2017

Teknik pengumpulan data dilakukan dengan cara observasi, wawancara, dan kuesioner. Teknik analisis data yang dilakukan meliputi uji validitas, uji reliabilitas, analisis statistik deskriptif, uji normalitas, uji multikolinieritas, uji heteroskedastisitas, uji parsial (uji t), uji simultan (uji F), dan koefisien determinasi $\mathrm{R}^{2}$. Penelitian ini menggunakan rancangan penelitian berdasarkan prosedur statistik yang pengolahannya menggunakan aplikasi IBM SPSS Statistics 21. 
Faktor Yang Mempengaruhi.... (Indah, Bergas)

\section{HASIL DAN PEMBAHASAN}

Hasil analisis deskriptif menunjukkan bahwa nilai rata-rata untuk variabel implementasi SAK ETAP sebesar 51,44 yang menunjukkan bahwa implementasi SAK ETAP pada UMKM Jamur tiram di Kabupaten Temanggung berada dalam kategori sedang. Nilai ratarata variabel latar belakang pendidikan pemilik UMKM Jamur tiram di Kabupaten Temanggung, dapat dilihat ditarik kesimpulan bahwa frekuensi responden terbanyak memiliki latar belakang pendidikan SMA yaitu sebanyak 31. Variabel ukuran usaha sebesar 4,6 berada pada kriteria sangat kecil. Variabel umur usaha rata-rata sebesar 5,39. Variabel pemahaman teknologi pemilik UMKM jamur tiram memiliki rata-rata sebesar 30,5. Varriabel sosialisasi dan pelatihan yang telah didapatkan pemilik UMKM jamur tiram memiliki rata-rata sebesar 25,8. dan nilai rata-rata variabel ketidakpastian lingkungan yang dialami UMKM jamur tiram sebesar 30,7.

Uji normalitas dapat dilakukan dengan menggunakan uji KolmogorovSmirnov, dilihat dari variabel pengganggu atau residual memiliki nilai asymptotic significant sebesar 0,200 (lebih besar dari
0,05) yang mengindikasikan bahwa data tersebut terdistribusi secara normal. Hasil Uji multikolonieritas menunjukkan besaran korelasi antar variabel independen masih dibawah 0,90 atau $90 \%$ maka dapat dikatakan tidak terjadi multikolinearitas yang serius. Hasil uji heteroskedastisitas diketahui bahwa $\mathrm{C}^{2}$ hitung lebih kecil dari $\mathrm{C}^{2}$ tabel sehingga dapat disimpulkan bahwa tidak terdapat heteroskedastisitas pada model regresi..

Uji hipotesis menunjukkan nilai adjusted $\mathrm{R}^{2}$ sebesar 0,846. Hal ini menunjukkan bahwa $84,6 \%$ variasi dari implementasi SAK ETAP latar belakang pendidikan, ukuran usaha, umur usaha, pemahaman teknologi, sosialisasi dan pelatihan, interkasi latar belakang pendidikan-ketidakpastian lingkungan, ukuran usaha-ketidakpastian lingkungan, umur usaha-ketidakpastian lingkungan, pemahaman teknologi-ketidakpastian lingkungan, sosialisasi dan pelatihanketidakpastian lingkungan. Sedangkan sisanya yaitu $23,4 \%$ dijelaskan oleh variabel lain diluar model penelitian ini. Hasil pengujian hipotesis dapat dilihat pada tabel 2 dengan nilai $\alpha$ sebesar 0,05 .

Tabel 2. Hasil Uji Hipotesis

\begin{tabular}{llccc}
\hline \multicolumn{1}{c}{ Hipotesis } & B & Sig & Hasil \\
\hline $\mathrm{H}_{1}$ & $\begin{array}{l}\text { Latar belakang pendidikan berpengaruh } \\
\text { positif terhadap implementasi SAK ETAP. }\end{array}$ & $-6,362$ & 0,646 & Ditolak \\
$\mathrm{H}_{2}$ & $\begin{array}{l}\text { Ukuran usaha berpengaruh positif terhadap } \\
\text { implementasi SAK ETAP. }\end{array}$ & $-17,267$ & 0,067 & Ditolak \\
$\mathrm{H}_{3}$ & $\begin{array}{l}\text { Umur usaha berpengaruh positif terhadap } \\
\text { implementasi SAK ETAP. }\end{array}$ & $-31,724$ & 0,020 & Ditolak \\
$\mathrm{H}_{4} \quad \begin{array}{l}\text { Pemahaman teknologi berpengaruh positif } \\
\text { terhadap implementasi SAK ETAP. }\end{array}$ & $-1,188$ & 0,606 & Ditolak \\
$\mathrm{H}_{5}$ & $\begin{array}{l}\text { Sosialisasi dan pelatihan berpengaruh positif } \\
\text { terhadap implementasi SAK ETAP. } \\
\text { Terdapat pengaruh signifikan antara latar } \\
\text { belakang pendidikan dan implementasi SAK } \\
\text { ETAP yang dimoderasi ketidakpastian } \\
\text { lingkungan }\end{array}$ & $0,319,233$ & 0,002 & Diterima \\
& & & 0,476 & Ditolak \\
\end{tabular}




\begin{tabular}{lllcc}
\hline \multicolumn{1}{c}{ Hipotesis } & B & Sig & Hasil \\
\hline $\mathrm{H}_{7}$ & $\begin{array}{l}\text { Terdapat pengaruh signifikan antara ukuran } \\
\text { usaha dan implementasi SAK ETAP yang } \\
\text { dimoderasi ketidakpastian lingkungan. } \\
\mathrm{H}_{8}\end{array}$ & 0,630 & 0,043 & Diterima \\
& $\begin{array}{l}\text { Terdapat pengaruh signifikan antara umur } \\
\text { usaha dan implementasi SAK ETAP yang } \\
\text { dimoderasi ketidakpastian lingkungan. }\end{array}$ & 1,019 & 0,021 & Diterima \\
$\mathrm{H}_{9}$ & $\begin{array}{l}\text { Terdapat pengaruh signifikan antara } \\
\text { pemahaman teknologi dan implementasi }\end{array}$ & 0,063 & 0,399 & Ditolak \\
& $\begin{array}{l}\text { SAK ETAP yang dimoderasi ketidakpastian } \\
\text { lingkungan. } \\
\text { Terdapat pengaruh signifikan antara } \\
\text { sosialisasi dan pelatihan dan implementasi } \\
\text { SAK ETAP yang dimoderasi ketidakpastian } \\
\text { lingkungan }\end{array}$ & & & \\
Sumber: Data sekunder diolah, 2018 & & 0,322 & Diterima
\end{tabular}

\section{Pengaruh Latar Belakang Pendidikan Terhadap Implementasi SAK ETAP}

Pengujian hipotesis menunjukkan bahwa latar belakang pendidikan tidak berpengaruh terhadap implementasi SAK ETAP hal ini tidak sesuai dengan Human Capital Theory oleh Becker (1965) yang menyatakan bahwa pendidikan menanamkan ilmu pengetahuan, ketrampilan, dan nilai-nilai kepada manusia karenanya mereka dapat meningkatkan kapasitas belajar dan produksinya. Menurut Zahro \& Wahyundaru (2015) pentingnya latar belakang pendidikan yang dimiliki oleh pemilik UMKM bertujuan untuk mengimplementasikan pendidikan yang telah diperoleh dan menghasilkan pengambilan keputusan yang baik dalam mencapai efisiensi dan efektivitas dalam kegiatan usaha. Semakin mudah untuk diaksesnya sumber informasi mengenai pembukuan dan pencatatan akuntasi sehingga dapat meningkatkan pemahaman para pelaku UMKM dalam menerapkan pelaporan keuangan sesuai dengan standar yang ada, dalam hal ini khususnya SAK ETAP. Hasil penelitian ini sejalan dengan penelitian Meidiyustiani (2016), Rudiantoro \& Siregar (2012) serta Zahro
\& Wahyundaru (2015) yang menyatakan bahwa latar belakang pendidikan tidak berpengaruh terhadap implementasi SAK ETAP.

\section{Pengaruh Ukuran Usaha Terhadap Implementasi SAK ETAP}

Pengujian hipotesis menunjukkan bahwa ukuran usaha tidak berpengaruh terhadap implementasi SAK ETAP pada UMKM jamur tiram di Kabupaten Temanggung. Hasil penelitian ini bertentangan dengan UTAUT yang menyatakan bahwa dalam mengadopsi sebuah sistem teknologi (dalam hal ini adalah SAK ETAP, karena akuntansi adalah soft technology akan terpenuhi apabila adanya kondisi yang mendukung. Dimana ukuran usaha yang besar berimplikasi perusahaan lebih dapat menyediakan fasilitas yang mendukung.

Hasil ini sejalan dengan penelitian yang dilakukan oleh Tuti \& Dwiyanti (2015) yang menyatakan bahwa ukuran usaha tidak berpengaruh terhadap implementasi SAK ETAP. Hasil penelitian ini bertentangan dengan penelitian yang dilakukan oleh Aufar (2014) serta Holmes \& Nicholls (1988) yang menyatakan bahwa ukuran usaha yang tinggi akan berpengaruh terhadap 
implementasi informasi akuntansi dalam hal ini SAK ETAP.

Hasil penelitian ini menemukan bahwa ukuran usaha tidak berpengaruh terhadap implementasi SAK ETAP pada UMKM, ukuran usaha yang semakin besar memberikan keuntungan dalam hal sumber daya yang lebih besar dan juga lebih mampu memperkerjakan karyawan dengan keahlian yang lebih baik. Akan tetapi ukuran usaha yang besar akan memberikan kompleksitas dan semakin tingginya tingkat transaksi perusahaan akibat semakin banyak modal yang tertanam dalam perusahaan tesebut, semakin banyak penjualan yang dapat dihasilkan oleh suatu perusahaan maka akan semakin tinggi pula perputaran uang dan semakin besar kapitalisasi pasar. Sehingga penyebab ukuran usaha tidak berpengaruh signifikan tersebut dapat disebabkan oleh beberapa hal, yaitu bisa dipengaruhi oleh kepribadian dan motivasi pemilik UMKM.

\section{Pengaruh Umur Usaha Terhadap Implementasi SAK ETAP}

Pengujian hipotesis menunjukkan bahwa umur usaha berpengaruh negatif terhadap implementasi SAK ETAP pada UMKM. Umur usaha yang semakin panjang memberikan keuntungan dalam hal telah mempunyai struktur dan proses yang rutin yang mendisiplinkan setiap tindakan perusahaan, akan tetapi juga terdapat usaha yang sudah lama berdiri tetapi tidak melakukan pencatatan laporan keuangan. Sementara ada usaha yang baru berdiri sudah melakukan pencatatan laporan keuangan, menurut Rudiantoro \& Siregar (2012) menyatakan bahwa pada saat usaha baru berdiri akan mendorong seorang pengusaha untuk lebih giat mencari informasi dan cara untuk dapat mengembangkan usahanya di masa yang akan datang. Sesuai dengan data responden bahwa banyak dari pelaku UMKM jamur tiram yang tergolong usaha baru berdiri tetapi telah menerapkan pembukuan sesuai dengan SAK ETAP. Mereka melakukan pembukuan karena untuk mempermudah dalam mengetahui kegiatan perusahaan mereka mengenai laba rugi serta khususnya untuk mempermudah di dalam mengajukan permodalan.

\section{Pengaruh Pemahaman Teknologi Terhadap Implementasi SAK ETAP}

Pengujian hipotesis menunjukkan bahwa pemahaman teknologi tidak berpengaruh terhadap implementasi SAK ETAP. Hal ini tidak sejalan dengan UTAUT yang dikembangkan oleh Venkatesh et al., (2011). UTAUT menyebutkan bahwa penentu inti dari suatu niat dan pengguna teknologi informasi salah satunya adalah ekspektasi terhadap upaya (effort expectancy) yaitu sejauh mana tingkat kemudahan yang dirasakan oleh individu dalam menggunakan sistem. Upaya untuk memahami teknologi informasi yang baru dapat merubah pandangan para pelaku UMKM terhadap berbagai bentuk penerapan teknologi yang semakin luas dalam menjalankan bisnisnya. Penelitian ini memberikan bukti empiris bahwa tidak ada keterkaitan antara pemahaman teknologi dan implementasi SAK ETAP. Hasil ini sejalan dengan penelitian yang dilakukan oleh Zahro \& Wahyundaru (2015) serta Agung et al., (2018) yang menyatakan bahwa pemahaman teknologi tidak berpengaruh terhadap implementasi SAK ETAP. Secara teori pentingnya pemahaman teknologi informasi bertujuan untuk mengadopsi dan memanfaatkan suatu informasi akuntansi, sebab informasi akuntansi digunakan sebagai pedoman dalam pengambilan keputusan, mencapai efisiensi dan efektifitas kegiatan usaha tetapi sesuai dengan data responden bahwa pemahaman teknologi menjadi faktor motivasi responden dalam menerapkan SAK ETAP meskipun secara 
pemahan teknologi mereka tergolong cukup.

\section{Pengaruh Sosialisasi dan Pelatihan Terhadap Implementasi SAK ETAP}

Pengujian hipotesis menunjukkan bahwa sosialiasi dan pelatihan berpengaruh posistif terhadap implementasi SAK ETAP sejalan dengan UTAUT menyatakan bahwa penentu pengguna teknologi informasi salah satunya adalah pengaruh sosial (social influnce) yaitu sejauh mana persepsi suatu individu akan keyakinan orang lain dalam menggunakan sistem baru Venkatesh et al., (2011). Sosialisasi yang diterima pemilik UMKM merupakan pengaruh sosial yang dapat mempengaruhi persepsi pemilik UMKM untuk menerapkan SAK ETAP. Hasil penelitian ini sejalan dengan penelitian yang dilakukan oleh Firmansyah (2013) dan Solovida (2003) yang meyatakan bahwa sosialisasi dan pelatihan berpengaruh positif terhadap penggunaan sistem akuntansi dalam hal ini adalah SK ETAP pada usaha kecil.

\section{Pengaruh Latar Belakang Pendidikan Terhadap Implementasi SAK ETAP dengan dimoderasi oleh Ketidakpastian Lingkungan}

Pegujian hipotesis menunjukkan bahwa latar belakang pendidikan dan ketidakpastian lingkungan tidak berpengaruh signifikan terhadap implementasi SAK ETAP. Hasil tersebut diartikan bahwa ketidakpastian lingkungan tidak dapat memoderasi pengaruh latar belakang pendidikan terhadap implementasi SAK ETAP.

Hasil penelitian ini mematahkan teori Human Capital Theory yang mendasari hipotesis keenam penelitian ini. Hal tersebut dikarenakan berdasarkan analisis deskriptif latar belakang pendidikan yang dimiliki sebagian besar responden dalam penelitian ini tergolong SMA/SMK yang tergolong tinggi. Namun hal tersebut tidak memiliki pengaruh terhadap tingkat implementasi SAK ETAP yang dilakukan oleh pelaku UMKM. Di sisi lain, penelitian ini menggunakan ketidakpstian lingkungan yang dirasakan pelaku UMKM sebagai variabel moderasi, tetapi pada kenyataannya hasil penelitian menunjukkan bahwa ketidakpstian lingkungan tidak dapat memperkuat ataupun memperlemah hubungan antara latar belakang pendidikan dan implementasi SAK ETAP. Berdasarkan hasil wawancara dengan responden bahwa ketidakpastian lingkungan yang dihadapi oleh UMKM belum tentu akan meningkatkan penggunaan informasi akuntansi (SAK ETAP). Hal ini dikarenakan pemilik usaha yang memiliki latar belakang pendidikan tinggi, tidak semata-mata menggunakan informasi akuntansi dikarenakan adanya ketidakpastian lingkungan, melainkan sebagai bentuk pengaplikasian dari ilmu dan pengetahuan yang dimiliki terhadap usahanya. Hasil tersebut sejalan dengan penelitian yang dilakukan oleh Sitoresmi \& Fuad (2013), Ernawati, (2016).

\section{Pengaruh Ukuran Usaha Terhadap Implementasi SAK ETAP dengan dimoderasi oleh Ketidakpastian Lingkungan \\ Ketidakpastian lingkungan \\ berpengaruh signifikan terhadap} implementasi SAK ETAP dengan arah positif. Hasil tersebut diartikan bahwa ketidakpastian lingkungan memperkuat pengaruh ukuran usaha terhadap implementasi SAK ETAP, maka disimpulkan hipotesis ketujuh diterima.

Berdasarkan hasil tersebut diperoleh kesimpulan bahwa setelah adanya moderasi dari variabel ketidakpastian lingkungan, pengaruh ukuran perusahaan terhadap implementasi SAK ETAP menunjukkan arah positif. Artinya bahwa ukuran usaha yang 
dimiliki UMKM dapat menaikkan implementasi SAK ETAP dengan adanya ketidakpastian lingkungan yang dirasakan pemilik UMKM. Hasil penelitian ini sejalan dengan penelitian yang dilakukan oleh Yasa, Herawati, \& Sulindawati (2017), Lasdi \& Winda Mulia (2014) serta Nahar \& Widiastuti (2011) mereka beranggapan bahwa variabel ketidakpastian lingkungan memperkuat pengaruh atara ukuran usaha terhadap penggunaan informasi akuntansi dalam hal ini adalah SAK ETAP.

\section{Pengaruh Umur Usaha Terhadap Implementasi SAK ETAP dengan dimoderasi oleh Ketidakpastian Lingkungan}

Pegujian hipotesis menunjukkan bahwa umur usaha dan ketidakpastian lingkungan berpengaruh signifikan terhadap implementasi SAK ETAP dengan arah positif. Hal tersebut berarti jika umur usaha yang dimiliki UMKM termasuk ke dalam kategori lama, demikian juga ketidakpastian lingkungan yang dirasakan pelaku UMKM tinggi, akan menimbulkan pelaku UMKM menyadari pentingnya implementasi SAK ETAP.

Berdasakan hasil penelitian tersebut berarti jika umur usaha yang dimiliki UMKM termasuk ke dalam kategori lama, demikian juga ketidakpastian lingkungan yang dirasakan pelaku UMKM tinggi, akan menimbulkan pelaku UMKM menyadari pentingnya implementasi SAK ETAP. Hasil hipotesis ini sesuai dengan penelitian Setyaningrum et al., (2016) dan (Yasa et al., 2017) yang mengatakan bahwa ketidakpastian lingkungan memperkuat pengaruh umur usaha terhadap penggunaan informasi akuntasi dalam hal ini SAK ETAP. Dapat dilihat dari masa pemilik atau pemimpin usaha dalam mengoperasionalkan usahanya, semakin lama dalam mengelola usaha maka semakin cepat dalam memprediksi kondisi lingkungan ekternal yang terjadi dan yang dapat mempengaruhi operasional usahanya. Semakin tinggi ketidakpastian lingkungan yang dirasakan pemilik UMKM jamur tiram di Kabupaten Temanggung, pemilik usaha mungkin membutuhkan tambahan informasi untuk menanggulangi kompleksitas dari lingkungan.

\section{Pengaruh Pemahaman Teknologi Terhadap Implementasi SAK ETAP dengan dimoderasi oleh Ketidakpastian Lingkungan}

Pengujian hipotesis menunjukkan bahwa pemahaman teknologi dan ketidakpastian lingkungan tidak berpengaruh signifikan terhadap implementasi SAK ETAP dengan arah positif. Hasil tersebut diartikan bahwa ketidakpastian lingkungan tidak dapat memoderasi pengaruh pemahaman teknologi terhadap implementasi SAK ETAP.

Hasil tersebut mematahkan UTAUT yang mendasari hipotesis kesembilan penelitian ini. Hal tersebut dikarenakan tingkat pemahaman teknologi yang dimiliki sebagian besar responden dalam penelitian ini tergolong tinggi. Namun hal tersebut tidak memiliki pengaruh terhadap tingkat implementasi SAK ETAP yang dilakukan oleh pelaku UMKM. Di sisi lain, penelitian ini menggunakan ketidakpastian lingkungan yang dirasakan pelaku UMKM sebagai variabel moderasi, tetapi pada kenyataannya hasil penelitian menunjukkan bahwa ketidakpastian lingkungan tidak dapat memperkuat ataupun memperlemah hubungan antara pemahaman teknologi dan implementasi SAK ETAP. Hasil penelitian ini didukung oleh data wawancara dengan responden bahwa pemahaman tentang teknologi informasi kurang dalam mendorong UMKM jamur tiram di Kabupaten Temanggung untuk memahami pentingnya implementasi 
SAK ETAP bagi UMKM. Secara teori pentingnya pemahaman teknologi informasi bertujuan untuk mengadopsi dan memanfaatkan suatu informasi akuntansi, sebab informasi akuntansi digunakan sebagai pedoman dalam pengambilan keputusan, mencapai efisiensi dan efektifitas kegiatan usaha. Faktor ketidakpastian lingkungan tidak dapat menjadi faktor motivasi responden dalam menerapkan SAK ETAP meskipun secara pemahan teknologi mereka tergolong cukup.

\section{Pengaruh Sosialisasi dan Pelatihan Terhadap Implementasi SAK ETAP dengan dimoderasi oleh Ketidakpastian Lingkungan}

Pengujian hipotesis menunjukkan bahwa ketidakpastian lingkungan dan sosialisasi dan pelatihan berpengaruh signifikan terhadap implementasi SAK ETAP dengan arah positif. Hasil tersebut diartikan bahwa ketidakpastian lingkungan memperlemah pengaruh sosialisasi dan pelatihan berpengaruh signifikan terhadap implementasi SAK ETAP. Hal tersebut sejalan dengan UTAUT menyatakan bahwa penentu pengguna teknologi informasi salah satunya adalah pengaruh sosial (social influnce). Adanya interkasi antara variabel sosialisasi dan pelatihan dan ketidakpastian lingkungan dalam penelitian ini memberikan hasil bahwa interaksi kedua variabel tersebut memiliki pengaruh terhadap perilaku disfungsional audit dengan arah positif.

Hasil penelitian ini yang

membuktikan bahwa variabel ketidakpastian lingkugan memperkuat pengaruh sosialisasi dan pelatihan terhadap Implementasi SAK ETAP sejalan dengan penelitian yang di lakukan oleh Huda (2017). Hal tersebut didukung oleh hasil wawancara dengan respondek yakni pelaku UMKM jamur tiram di Kabupaten Temanggung, bahwa semakin banyak sosialisasi dan pelatihan yang di dapat oleh responden akan mempermudah di dalam mengatasi ketidakpastian lingkungan yang mungkin akan dihadapi UMKM.

\section{SIMPULAN}

Simpulan penelitian ini adalah implementasi SAK ETAP dipengaruhi oleh latar belakang pendidikan, ukuran usaha, umur usaha, pemahaman teknologi, serta sosialisasi dan pelatihan. Keenam hipotesis yang ditolak adalah pengaruh latar belakang pendidikan, ukuran usaha, pemahaman teknologi terhadap implementasi SAK ETAP, serta pengaruh latar belakang pendidikan, pemahaman teknologi, serta sosialisasi dan pelatihan terhadap implementasi SAK ETAP dimoderasi ketidakpastian lingkungan. Saran untuk penelitian selanjutnya yaitu menambah variabel independen lain seperti menambah variabel independen lain seperti persepsi pengusaha dan budaya organisasi yang diperkirakan dapat mempengaruhi implementasi SAK ETAP. 
Faktor Yang Mempengaruhi.... (Indah, Bergas)

\section{DAFTAR PUSTAKA}

Afianti, P. (2017). Faktor-Faktor yang Mempengaruhi Penerapan Standar Akuntansi Keuangan Entitas Tanpa Akuntabilitas Publik (SAK ETAP) Pada Umkm Di Kabupaten Bogor. In Skripsi.

Agung, A., Latuheru, B. P., \& Persulessy, G. (2018). Faktor-Faktor Yang Mempengaruhi Penerapan Standar Akuntansi Keuangan Entitas Tanpa Akuntabilitas Publik. Jurnal Ekonomi, Volume 12, Hal 105-136.

Aufar, A. (2014). Faktor-Faktor yang Mempengaruhi Penggunaan Informasi Akuntansi pada UMKM (Usaha Mikro, Kecil, dan Menengah) (Survei Pada Perusahaan Rekanan PT. PLN (Persero) di Kota Bnadung). Bandung: Universitas Widyatama.

Azis, A., Riyanto, B. E., Renaningsih, T., \& Sriwahyuni, S. (2015). Peran Penerapan SAK ETAP Terhadap Akses UMKM Dengan Lembaga Keuangan, 1-8.

Becker, G. S. (1965). Investment in Human Capital: A Theoritical Analysis. The Journal of Polotical Economy, Volume 70, 9-49.

Cushway, B. (1994). Human Resource Management. Jakarta: Elex Media Computindo, Kelompok Gramedia.

Duncan, R. B. (2012). Characteristics of Organizational Environments and Perceived Enviromental Uncertainty. Administrative Science Quarterly, 17 No.3, 313-327.

Ernawati, D. (2016). Pengaruh Karakteritik Usaha Terhadap Penggunaan Informasi Akuntansi Dengan Ketidakpastian Lingkungan Sebagai Variabel Moderasi (Studi pada UKM dikabupaten Jember). Jurnal Mahasiswa FEB Universitas Muhammadiyah Jember.

Firmansyah, R. A. (2013). Faktor-Faktor yang Mempengaruhi Penggunaan
Sistem Informasi Akuntansi pada Usaha Kecil dan Menengah di Kota Malang. Jurnal Ilmiah Mahasiswa FEB Universitas Brawijaya, Vol.2 No.2.

Gray, R., Adams, C. A., González, C. L., Adams, C. A., \& Mcnicholas, P. (2010). Users who downloaded this article also downloaded: Social, environmental and sustainability reporting and organisational value creation? Whose value? Whose creation?

https://doi.org/10.1108/09513570610 709872

Hasibuan, M. S. P. (2006). Manajemen Dasar, Pengertian, dan Masalah. Jakarta: Bumi Aksara.

Holmes, S., \& Nicholls, D. (1988). An Analysis of The Use of Accounting Information by Australian Small Business. Journal of Small Business Management, 26(2)(57-68).

Huda, C. (2017). Pengaruh Tingkat Pendidikan Pemilik, Pengetahuan Akuntansi dan Pelatihan Akuntansi Terhadap Penggunaan Informasi Akuntansi Dimoderasi Ketidakpastian Lingkungan Usaha Kecil Menengah. Jurnal Ilmiah FEB UNESA, Vol.5 No.1.

Ikatan, I. A. (2009). Standar Akuntansi Keuangan Entitas Tanpa Akuntabilitas Publik.

Lasdi, L., \& Winda Mulia, T. (2014). Company's Internal

Characteristics,Environmental Uncertainty, The Use of Accounting Information, and The Performance of SMEs. Journal of Economics, Business, and Accountancy Ventura, Vol.17 No.

Meidiyustiani, R. (2016). Pengaruh Pendidikan Pemilik, Pemahaman Akuntansi, dan Motivasi Pemilik Terhadap Penerapan Standar Akuntansi Keuangan Untuk Entitas Tanpa Akuntabilitas Publik (SAK 
ETAP) (Studi Empiris: Perusahaan Kecil dan Menengah di Kota Semarang), Vol.1 No.1.

Milliken, F. J. (1987). Three Types of Perceived Uncertainty About the Environment: State , Effect , and Response Uncertainty. Academy of Management Review, 12(1), 133143.

Mulyaga, F. (2016). Faktor Faktor yang Mempengaruhi Implementasi Standar Akuntansi Keuangan Entitas Tanpa Akuntabilitas Publik Pada UMKM. In Skripsi. Semarang: Universitas Negeri Semarang.

Nahar, A., \& Widiastuti, A. (2011). Analisis Penggunaan Informasi Akuntansi pada Industri Menengah di Kabupaten Jepara. In Seminar Nasional Teknologi Informasi \& Komunikasi (Vol. 2011, pp. 0-5).

Nugroho, A. (2012). Faktor-Faktor yang Mempengaruhi Intellectual Capital Disclosure (ICD). Accounting Analysis Journal, 1(2).

Pratiwi, N. B., \& Hanafi, R. (2016). Analisis Faktor yang Mempengaruhi Penerapan Standar Akuntansi Keuangan Entitas Tanpa Akuntabilitas Publik (SAK ETAP) Pada Usaha Mikro Kecil dan Menengah (UMKM). Jurnal Akuntansi Indonesia, 5 No.1, 79-98.

Rudiantoro, R., \& Siregar, S. V. (2011). Kualitas Laporan Keuangan UMKM Serta Prospek Implementasi SAK ETAP. Simposium Nasional Akuntansi XIV Aceh 2011, 1-32.

Rudiantoro, R., \& Siregar, S. V. (2012). Kualitas Laporan Keuangan UMKM serta Prospek Implementasi SAK ETAP. Jurnal Akuntansi Dan Keuangan Indonesia, 9(1), 1-21.

Sariningtyas, P., \& W, T. D. (2011). Standar Akuntansi Keuangan Entitas Tanpa Akuntabilitas Publik Pada Usaha Kecil dan Menengah. Jurnal Akuntansi Dan Keuangan Indonesia,
1(1), 90-101.

Seftianne. (2011). Faktor-Faktor yang Mempengaruhi Struktural Modal Pada Perusahaan Publik Sektor Manufaktur. Jurnal Bisnis Dan Akuntansi, Volume 13, 39-56.

Setyaningrum, D., Wiratno, A., \& Sukirman. (2016). Pengaruh Pendidikan Pemilik, Pengetahuan Akuntansi Pemilik, Budaya Perusahaan, dan Umur Usaha Terhadap Penggunaan Informasi Akuntansi Pada UKM dengan Ketidakpastian Lingkungan sebagai Variabel Pemoderasi (Studi Empiris Terhadap UKM yang Menghasilkan Produ, 3, 529-543.

Sitoresmi, L. D., \& Fuad. (2013). FaktorFaktor yang Mempengaruhi Penggunaan Informasi Akuntansi Pada Usaha Kecil dan Menengah (Studi Pada KUB Sido Rukun Semarang). Diponegoro Journal of Accounting, Volume 2 N(1-13).

Solovida, G. T. (2003). Analisis FaktorFaktor yang Mempengaruhi Penyiapan dan Penggunaan Informasi Akuntansi Pada Perusahaan Kecil dan Menengah di Jawa Tengah. In Tesis. Semarang: Universitas Diponegoro.

Soraya, E. A., \& Mahmud, A. (2016). Faktor-Faktor yang Mempengaruhi Kebutuhan Standar Akuntansi Keuangan Entitas Tanpa Akuntabilitas Publik. Accounting Analysis Journal, 5(1).

Tuti, R., \& S, P. F. D. (2015). FaktorFaktor yang Mempengaruhi Pemahaman UMKM Dalam Menyusun Laporan Keuangan Berdasarkan SAK ETAP, (19786522).

Undang-Undang Nomor 20 Tahun 2008. (n.d.). $U M K M$.

Venkatesh, V., Thong, J. Y. ., \& Chan, F. K. . (2011). Extending The TwoStage Information System 
Faktor Yang Mempengaruhi.... (Indah, Bergas)

Continuance Model: Incorporating UTAUT Predictor And The Role of Contect. Info System Journal, 21, 527-555.

Wahyudin, A., \& Khafid, M. (2013). Akuntansi Dasar. Semarang: Unnes Press.

Wulandary, C., \& Hidayat., D. (2012). Analisis Faktor-Faktor yang Mempengaruhi Penyiapan dan Penggunaan Informasi Akuntansi pada Perusahaan Kecil dan Menengah di Kota Pekanbaru. Jurnal Ekonomi, Manajemen Dan Akutansi I, Vol.19 No.

Yanto, H., Yulianto, A., Sebayang, L. K., \& Mulyaga, F. (2017). Improving The Compliance With Accounting Standards Without Public Accountability (SAK ETAP) By Developing Organizational Culture: A Case of Indonesia SMEs. The
Journal of Applied Business Research, 33 Number, 929-940.

Yasa, K. S. H., Herawati, N. T., \& Sulindawati, N. L. G. E. (2017). Pengaruh Skala Usaha, Umur Perusahaan, Pengetahuan dan Akuntansi Terhadap Penggunaan Informasi Akuntansi pada Usaha Kecil Menengah (UKM) di Kecamatan Buleleng dengan Ketidakpastian Lingkungan Sebagai Variabel Pemoderasi. E-Journal S1 Ak Universitas Pendidikan Ganesha, $8(2)$.

Zahro, F., \& Wahyundaru, S. D. (2015). Determinan Kebutuhan SAK ETAP Bagi UKM (Studi Empiris Pada UKM Makanan di Kota Semarang). Conference Business, Accounting and Management, 2 No.1. 